Annals of Plant and Soil Research 23(2): 140-144 (2021)

https://doi.org/10.47815/apsr.2021.10046

\title{
Effect of integrated potassium management on growth, yield and nutrient uptake of wheat (Triticum aestivum)
}

\section{ANIL KUMAR AND DEVENDRA KUMAR}

\author{
Department of Agricultural Chemistry \& Soil Science, RB (P G) College, Jalesar Road, Agra (U.P.)-282006
}

Received: January, 2021; Revised accepted: March, 2021

\begin{abstract}
A field experiment was conducted during rabi seasons of2017-19 at Panwari village, Agra (U.P.) to assess the effect of integrated potassium management on growth, yield and uptake of nutrient in wheat (Triticum aestivum). The experiment was laidout in a randomized block design with seven treatments and three replications. The results revealed that increasing levels of $K$ fertilizers increased the growth and yield attributes up to $90 \mathrm{Kg} \mathrm{K} \mathrm{K}_{2} \mathrm{O} \mathrm{ha}^{-1}$ over control. But the growth and yield attributes of wheat were maximum with the application of $150 \mathrm{Kg} \mathrm{N}+60 \mathrm{Kg} \mathrm{P}_{2} \mathrm{O}_{5}+60 \mathrm{Kg} \mathrm{K}_{2} \mathrm{O}+5 \mathrm{t} \mathrm{FYM} \mathrm{ha}{ }^{-1}$. Increasing levels of NPK fertilizers increased the yield of wheat grain and straw over control. The maximum yield of grain $\left(5.48 t h^{-1}\right)$ and straw $\left(9.60 t h a^{-1}\right)$ were recorded with $N_{150} P_{60} K_{60} F Y M_{5}$. The increases in grain and straw yield with this treatment were 44.2 and $29.7 \%$ over control, respectively. The crop quality in respect of content and yield of protein increased significantly with conjoint use of fertilizers and maximum values were recorded with $150 \mathrm{Kg} \mathrm{N}+60 \mathrm{Kg} \mathrm{P}_{2} \mathrm{O}_{5}+$ $60 \mathrm{Kg} \mathrm{K} 2 \mathrm{O}+5 t \mathrm{FYM}$ ha ${ }^{-1}$ treatment. Increasing levels of NPK fertilizers up to $N_{150} P_{60} K_{90}$ also resulted in higher uptake of NPK by the crop and highest uptake of $N, P, K$ and $S$ by wheat crop was recorded with $N_{150}$ $P_{60} K_{60} F Y M_{5}$ and the lowest in control. The soil organic carbon, available $N, P$ and $K$ content also improved with $N_{150} P_{60} K_{60} F Y M_{5}$ over control and lowest values of these parameters were recorded in control.
\end{abstract}

Keywords:Integrated potassium management, nutrient uptake, yield, wheat

\section{INTRODUCTION}

Wheat (Triticum aestivum) is the most important staple food grain in Indian diet and main source of protein and calories for large section of population. Stagnation in wheat production, lower productivity and inferior quality of the produce is due to various constraints including inadequate and imbalanced nutrient application.Potassium plays an important role in the production phenology of wheat and the crop responds well to applied K (Singh etal.2015, Singh et al. 2020). Unfortunately, application of $\mathrm{K}$ did not receive due attention because of the general belief that Indian soils were believed to be adequate in native $\mathrm{K}$ supply. As a consequence, a continuous mismatch between nutrient removal and replenishment has been observed in various cropping systems even at the recommended level of fertilizer application. Increased availability of $\mathrm{K}$ improves the physical quality, disease resistance and shelf life of fruits and vegetables used for human consumption and feeding value of grain and forage crops. Potassium plays an important role in transport of nutrients and water in plants. There is a growing evidence of increasing deficiency of potassium as a result of imbalanced use of nitrogen and phosphorus (Subba Rao et al. 2017). Judicious use of organic manure with chemical fertilizers improves soil physical, chemical and biological properties and improves crop productivity (Pandey etal. 2020). Integration of chemical and organic sources and their efficient management have shown promising results not only in sustaining the production but also in maintaining soil health (Singh, 2020). Keeping in view the above facts, the present study was undertaken to assess the effect of applied organic and inorganick sources on yield and nutrient uptake in wheat crop.

\section{MATERIALS AND METHODS}

A field experiment was conducted during the winter season of 2017-18 and 2018-19 atPanwari village of Agra district, Uttar Pradesh $\left(27^{\circ} 2^{\prime} \mathrm{N}, 77^{\circ} 9^{\prime} \mathrm{E}, 163.4 \mathrm{~m}\right.$ above mean sea level).The experimental site is characterized by semi-arid climate with extreme temperature during summer $\left(45^{\circ}\right.$ to $\left.48^{\circ} \mathrm{C}\right)$ and very low temperature (as low as $2^{0} \mathrm{C}$ ). The average 
rainfall is about $650 \mathrm{~mm}$, most of which is received during June - September. The soil was sandy loam in texture having $\mathrm{pH} 7.8$, EC 0.27 $\mathrm{dSm}^{-1}$, organic carbon $3.1 \mathrm{~g} \mathrm{~kg}^{-1}$, available N160 $\mathrm{Kg} \mathrm{ha}{ }^{-1}$ available phosphorus $9.6 \mathrm{Kg} \mathrm{ha}^{-1}$, available potassium $112 \mathrm{Kg} \mathrm{ha}^{-1}$ and available Sulphur $14.5 \mathrm{Kg} \mathrm{ha}^{-1}$. The experiment was carried out using randomized block design with three replications and seven treatments. The detailsof the treatments were: $T_{1}$ control, $T_{2} 150$ $\mathrm{kg} \mathrm{N}+60 \mathrm{~kg} \mathrm{P}_{2} \mathrm{O}_{5} \mathrm{ha}^{-1}, \mathrm{~T}_{3} 150 \mathrm{~kg} \mathrm{~N}+60 \mathrm{~kg}$ $\mathrm{P}_{2} \mathrm{O}_{5}+30 \mathrm{~kg} \mathrm{~K}_{2} \mathrm{O} \mathrm{ha}^{-1}, \mathrm{~T}_{4} 150 \mathrm{~kg} \mathrm{~N}+60 \mathrm{~kg}$ $\mathrm{P}_{2} \mathrm{O}_{5}+30 \mathrm{~kg} \mathrm{~K} 2 \mathrm{O}+5$ t FYM ha-1, $\mathrm{T}_{5} 150 \mathrm{~kg} \mathrm{~N}+$ $60 \mathrm{~kg} \mathrm{P}_{2} \mathrm{O}_{5}+60 \mathrm{~kg} \mathrm{~K}_{2} \mathrm{O} \mathrm{ha}^{-1}, \mathrm{~T}_{6} 150 \mathrm{~kg} \mathrm{~N}+60$ $\mathrm{kg} \mathrm{P}_{2} \mathrm{O}_{5}+60 \mathrm{~kg} \mathrm{~K}_{2} \mathrm{O}+5 \mathrm{t} \mathrm{FYM} \mathrm{ha}^{-1}, \mathrm{~T}_{7} 150 \mathrm{~kg}$ $\mathrm{N}+60 \mathrm{~kg} \mathrm{P}_{2} \mathrm{O}_{5}+90 \mathrm{~kg} \mathrm{~K}_{2} \mathrm{O} \mathrm{ha}^{-1}$. Nitrogen, Phosphorus and potassium were applied through urea, DAP and muriate of potash, respectively. Full dose of $P$ and $K$ and half dose of $\mathrm{N}$ were applied basal and remaining half of $\mathrm{N}$ was given in 2 equal splits 30 and 60 daysafter sowing. Potassium and well decomposed FYM were applied as per treatments.Wheat PBW-502 was sown in rows, $20 \mathrm{~cm}$ apart using $100 \mathrm{~kg}$ seeds $\mathrm{ha}^{-1}$ in the second week of November during both the years. Other agronomic management practices were followed as per the standard recommendation. The crop was harvested at maturity and grain and straw yields were recorded. Plant height and yield attributes were also recorded at maturity. Grain and straw samples were digested with diacid mixture of $\mathrm{HNO}_{3}$ and $\mathrm{HClO}_{4}$ in 9:1 ratio. Phosphorus in the digest was determined by vanadomolybdophosphoric acid yellow color method (Jackson 1973). K by flamephotometer and sulphur by turbidimetric method (Chesnin and Yien 1951). Nitrogen in grain and straw was determined by modified Kjeldahl method. The nutrient removal by crop was calculated by multiplying the content values with their respective grain and straw yield values.Since trend of results was similar during both the years, data were subjected to sample of mean of two years indices for results and discussion. The experimental data were statistically analyzed for the differential effect of treatments by applying analysis of variance (ANOVA) technique for randomized block design as per the standard procedure (Gomez and Gomez, 1984).

\section{RESULT AND DISCUSSION}

\section{Growth and yield}

Significantly taller plants were recorded with the application of $\mathrm{N}_{150} \mathrm{P}_{60} \mathrm{~K}_{90}$ compared to $\begin{array}{lllll}\mathrm{N}_{150} & \mathrm{P}_{60} & \mathrm{~K}_{60} \text { and } & \mathrm{N}_{150} \mathrm{P}_{60} & \mathrm{~K}_{0} \text { treatments. The }\end{array}$ positive effect of inorganic fertilizers on plant height may be due to poor status of NPK in soil (Singh, 2020). Plant height also improved significantly over control with 30 and $60 \mathrm{~kg} \mathrm{~K} \mathrm{~K}_{2} \mathrm{O}$ $\mathrm{ha}^{-1}$ along with $5 \mathrm{t} \mathrm{FYM} \mathrm{ha-1}$. The tallest plants $(94.5 \mathrm{~cm})$ were recorded with $\mathrm{N}_{150} \mathrm{P}_{60} \mathrm{~K}_{60} \mathrm{FYM}_{5}$. This treatment was statistically at par with $90 \mathrm{~kg}$ $\mathrm{K}_{2} \mathrm{O} \mathrm{ha}^{-1}$ in respect of plant height. Adequate and continuous availability of nutrients with this treatment might have improved the plant height of wheat (Pandey etal. 2020). Significantly higher value of length of ear $(8.6 \mathrm{~cm})$ and grains ear $^{-1}$ (41.6) were also recorded with the application of $\mathrm{N}_{150} \mathrm{P}_{60} \mathrm{~K}_{60} \mathrm{FYM}_{5}$ treatment over other treatments. Application of $\mathrm{N}_{150} \mathrm{P}_{60} \mathrm{~K}_{90}$, being at par with $\mathrm{N}_{150} \mathrm{P}_{60} \mathrm{~K}_{60} \mathrm{FYM}_{5}$, showed a positive and significant effect on these yield attributes over most of the treatments owing to higher growth in terms of plant height with this treatment. This might be due to balanced use of fertilizers in soil which increased their availability in soil. In addition, it may be attributed to slow decomposition of FYM resulting in release of nutrients in synchrony with crop demand and their continuous availability in soil for higher number of ears and grains ear ${ }^{-1}$. Similar results were reported by Singh, (2020).

All the treatments applied with potassium showed significant superiority to no potassium treatment for both grain and straw yield of wheat (Table 1). Increase in grain and straw yield over the control was significant due to addition of 90 $\mathrm{kg} \mathrm{K}_{2} \mathrm{O}$ ha $^{-1}$. Higher response to the applied $\mathrm{K}$ was expected on this $\mathrm{K}$ deficient soil. The grain and straw yields of wheat were significantly influenced by combination of FYM and potassium. Application of $\mathrm{N}_{150} \mathrm{P}_{60} \quad \mathrm{~K}_{60} \quad \mathrm{FYM}_{5}$ recorded the highest mean grain (5.48 $\mathrm{t} \mathrm{ha}^{-1}$ ) and straw $\left(9.60 \mathrm{t} \mathrm{ha}^{-1}\right)$ yield of wheat which were 44.2 and $29.7 \%$ higher over control. Application of $N_{150} \mathrm{P}_{60} \mathrm{~K}_{60} \mathrm{FYM}_{5}$, being at par with $\mathrm{N}_{150} \mathrm{P}_{60}$ $\mathrm{K}_{90}$, was significantly superior to most of the treatments. The increase in yield was owing to the application of potassium as it plays a vital role in many plant processes including 
photosynthesis, translocation of photosynthates, protein synthesis, activation of plant enzymes etc. which leads greater number of grains ear $^{-1}$ and test weight which leads to higher yields. Similar results were reported by Kumar et al. (2015) and Singh etal. (2015).

Table1: Effect of integrated potassium management on growth, yield attributes and yield of wheat (pooled mean of 2 years)

\begin{tabular}{|c|c|c|c|c|c|c|c|c|c|}
\hline \multirow{2}{*}{ Treatment } & \multirow{2}{*}{$\begin{array}{l}\text { Plant Height } \\
(\mathrm{cm})\end{array}$} & \multirow{2}{*}{$\begin{array}{l}\text { Length of } \\
\text { ear }(\mathrm{cm})\end{array}$} & \multirow{2}{*}{$\begin{array}{c}\text { Grain } \\
\text { lear }\end{array}$} & \multirow{2}{*}{$\begin{array}{c}\text { Test } \\
\text { weight }(\mathrm{g})\end{array}$} & \multicolumn{2}{|c|}{ Yield $\left(\mathrm{t} \mathrm{ha}^{-1}\right)$} & \multicolumn{2}{|c|}{ Protein (\%) } & \multirow{2}{*}{$\begin{array}{c}\text { Protein } \\
\text { Yield }\left(\mathrm{kg} \mathrm{ha}^{-1}\right)\end{array}$} \\
\hline & & & & & Grain & Straw & Grain & Straw & \\
\hline Control & 85.3 & 8.0 & 37.8 & 38.5 & 3.80 & 7.40 & 12.0 & 3.4 & 456.0 \\
\hline$N_{150}$ & 87.6 & 8.1 & 38.5 & 38.6 & 4.44 & 8.45 & 12.5 & 3.7 & 555.0 \\
\hline $\mathrm{N}_{150} \mathrm{P}_{60} \mathrm{~K}_{30}$ & 89.2 & 8.3 & 39.0 & 38.7 & 4.67 & 8.90 & 12.6 & 3.8 & 588.4 \\
\hline $\mathrm{N}_{150} \mathrm{P}_{60} \mathrm{~K}_{30} \mathrm{FYM}_{5}$ & 92.0 & 8.5 & 41.0 & 39.0 & 4.98 & 9.10 & 12.8 & 3.9 & 637.4 \\
\hline $\mathrm{N}_{150} \mathrm{P}_{60} \mathrm{~K}_{60}$ & 91.6 & 8.4 & 40.0 & 38.8 & 5.05 & 9.45 & 12.7 & 3.8 & 641.3 \\
\hline${ }_{0} \mathrm{FYM}_{5}$ & 94.5 & 8.6 & 41.6 & 39.1 & 5.48 & 9.60 & 12.9 & 4.0 & 706.9 \\
\hline $\mathrm{N}_{150} \mathrm{P}$ & 94.0 & 8.4 & 41.0 & 38.9 & 5.20 & 9.50 & 12.8 & 3.8 & 665.6 \\
\hline SEm \pm & 1.03 & 0.09 & 1.18 & 0.25 & 0.05 & 0.13 & 0.07 & 0.04 & 4.95 \\
\hline$C D(P=0.05)$ & 2.79 & 0.25 & 3.28 & NS & 0.14 & 0.37 & 0.20 & 0.11 & 13.73 \\
\hline
\end{tabular}

\section{Quality}

There was significantly higher percentage of protein in grain and straw of wheat under all the treatments as compared to control. The protein content in grain ranged from 12 to 12.9 $\%$ and in straw from 3.4 to $4.0 \%$, the minimum being in control. Application of $\mathrm{N}_{150} \mathrm{P}_{60} \mathrm{~K}_{60} \mathrm{FYM}_{5}$, being at par with $\mathrm{N}_{150} \mathrm{P}_{60} \mathrm{~K}_{90}$, proved significantly superior to other treatments in respect of protein content in grain and straw. This may be due to accumulation of more nitrogen with these treatments and ultimately showing more protein per cent. The protein yield ranged from 456.0 to
$706.9 \mathrm{~kg} \mathrm{ha}^{-1}$. The minimum protein production was noted under control which may be attributed to lower grain yield of wheat. Protein production increased significantly with increasing levels of $K$ and higher values were recorded under $N_{150} P_{60}$ $\mathrm{K}_{90}$ treatment. Addition of $\mathrm{K}$ levels with $\mathrm{FYM}$ enhanced the protein production over $\mathrm{K}$ fertilization. The maximum protein yield (706.9

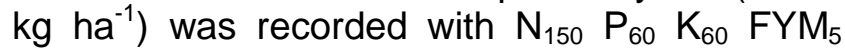
treatment showing the beneficial effect of combined use of chemical fertilizers and FYM. Similar results were reported by Singh and Patra (2017).

Table 2: Effect of integrated potassium management on uptake of nutrients $\left(\mathrm{Kg} \mathrm{ha}^{-1}\right)$ by wheat (mean of 2 year)

\begin{tabular}{|c|c|c|c|c|c|c|c|c|}
\hline \multirow{2}{*}{ Treatment } & \multicolumn{2}{|c|}{ Nitrogen } & \multicolumn{2}{|c|}{ Phosphorus } & \multicolumn{2}{|c|}{ Potassium } & \multicolumn{2}{|c|}{ Sulphur } \\
\hline & Grain & Straw & Grain & Straw & Grain & Straw & Grain & Straw \\
\hline Control & 72.9 & 40.7 & 8.3 & 7.4 & 22.0 & 139.1 & 9.1 & 9.6 \\
\hline $\mathrm{N}_{150} \mathrm{P}_{60} \mathrm{~K}_{0}$ & 88.8 & 50.7 & 11.1 & 10.1 & 25.7 & 159.7 & 11.5 & 11.8 \\
\hline $\mathrm{N}_{150} \mathrm{P}_{60} \mathrm{~K}_{30}$ & 94.3 & 54.3 & 12.1 & 11.5 & 28.0 & 171.7 & 12.1 & 12.4 \\
\hline $\mathrm{N}_{150} \mathrm{P}_{60} \mathrm{~K}_{30} \mathrm{FYM}_{5}$ & 102.0 & 59.8 & 13.9 & 14.2 & 31.1 & 181.3 & 13.9 & 15.2 \\
\hline $\mathrm{N}_{150} \mathrm{P}_{60} \mathrm{~K}_{60}$ & 102.5 & 59.5 & 10.9 & 13.4 & 32.3 & 184.2 & 13.6 & 14.4 \\
\hline $\mathrm{N}_{150} \mathrm{P}_{60} \mathrm{~K}_{60} \mathrm{FYM}_{5}$ & 112.8 & 61.4 & 15.8 & 15.1 & 35.6 & 186.2 & 15.8 & 17.0 \\
\hline $\mathrm{N}_{150} \mathrm{P}_{60} \mathrm{~K}_{90}$ & 106.6 & 56.8 & 14.5 & 12.8 & 34.8 & 185.3 & 14.0 & 14.6 \\
\hline SEm\# & 1.86 & 1.17 & 0.58 & 0.51 & 1.02 & 2.63 & 0.50 & 0.47 \\
\hline $\mathrm{CP}(\mathrm{P}=0.05)$ & 5.02 & 3.17 & 1.58 & 1.41 & 2.75 & 7.10 & 1.35 & 1.29 \\
\hline
\end{tabular}

\section{Nutrient uptake}

The combined use of potassium and FYM had significantly effect on the uptake of nutrients by wheat grain and straw (Table 2). All the treatments applied with potassium were significantly superior to no potassium treatments. The mean increases in $\mathrm{N}$ uptake by grain and straw were from 72.9 to $106.6 \mathrm{~kg} \mathrm{ha}^{-1}$ and 40.7 to $56.8 \mathrm{~kg} \mathrm{ha}^{-1}$, respectively with increase in the 
levels of $\mathrm{K}$ from control to $90 \mathrm{~kg} \mathrm{~K}_{2} \mathrm{O} \mathrm{ha}^{-1}$. The highest uptake of $\mathrm{N}$ by wheat was recorded with the application of $\mathrm{N}_{150} \mathrm{P}_{60} \mathrm{~K}_{60} \mathrm{FYM}_{5}$. Increasing levels of $\mathrm{K}$ up to $90 \mathrm{~kg} \mathrm{~K}_{2} \mathrm{O} \mathrm{ha}^{-1}$ increased the $\mathrm{P}$ uptake by grain and straw of wheat.Combined application of $\mathrm{K}$ and $\mathrm{FYM}$ also improved the utilization of $P$ by the crop and maximum values of $P$ uptake by grain $\left(15.8 \mathrm{~kg} \mathrm{ha}^{-1}\right)$ and straw $\left(15.1 \mathrm{Kg} \mathrm{ha}^{-1}\right)$ were recorded with $\mathrm{N}_{150} \mathrm{P}_{60} \mathrm{~K}_{60}$ $\mathrm{FYM}_{5}$ treatment. Application of $\mathrm{K}$ levels proved beneficial in increasing $\mathrm{K}$ uptake by wheat grain and straw over control (table 2).Combined application of $\mathrm{K}$ and $\mathrm{FYM}$ further improved the $\mathrm{K}$ utilization by crop over $\mathrm{K}$ levels alone. Application of $\begin{array}{lllll}\mathrm{N}_{150} & \mathrm{P}_{60} & \mathrm{~K}_{60} & \mathrm{FYM}_{5} \text { treatment }\end{array}$ absorbed the maximum quantities of $\mathrm{K}$ by wheat grain and straw. All the treatments proved beneficial in increasing the uptake of $S$ by wheat grain and straw over control and maximum values of $S$ uptake by the crop were recorded with $\mathrm{N}_{150} \mathrm{P}_{60} \mathrm{~K}_{60} \mathrm{FYM}_{5}$ treatment. The increased uptake of different nutrients was observed due to increased levels of $\mathrm{K}$, as it plays a vital role in translocation of nutrients that leads to increased nutrients uptake in plants. Potassium has synergistic effect on uptake of $\mathrm{N}$ and other nutrients due to which all the treatments applied with $\mathrm{K}$ showed superiority to the control.Kumar et al. (2015) reported that uptake of N, P and K was enhanced with increasing levels of $\mathrm{K}$.

Table 3: Effect of integrated use of potassium on $\mathrm{pH}$, organic carbon and available nutrients in postharvest

\begin{tabular}{l|c|c|ccccc|}
\hline \multirow{2}{*}{ Treatment } & \multirow{2}{*}{$\mathrm{pH}$} & \multirow{2}{*}{ Organic Carbon $\left(\mathrm{kgha}^{-1}\right)$} & \multicolumn{4}{c|}{ Available Nutrients $\left(\mathrm{kg} \mathrm{ha}^{-1}\right)$} \\
\cline { 4 - 7 } & & 2.8 & Nitrogen & Phosphorus & Potassium & Sulphur \\
\hline Control & 7.8 & 2.9 & 148 & 8.2 & 96 & 11.6 \\
$\mathrm{~N}_{150} \mathrm{P}_{60} \mathrm{~K}_{0}$ & 7.8 & 3.2 & 195 & 11.0 & 97 & 11.8 \\
$\mathrm{~N}_{150} \mathrm{P}_{60} \mathrm{~K}_{30}$ & 7.9 & 4.0 & 198 & 11.5 & 110 & 12.5 \\
$\mathrm{~N}_{150} \mathrm{P}_{60} \mathrm{~K}_{30}+\mathrm{FYM}_{5}$ & 7.5 & 3.5 & 210 & 14.0 & 125 & 15.0 \\
$\mathrm{~N}_{150} \mathrm{P}_{60} \mathrm{~K}_{60}$ & 7.8 & 4.5 & 200 & 12.0 & 123 & 13.0 \\
$\mathrm{~N}_{150} \mathrm{P}_{60} \mathrm{~K}_{60}+\mathrm{FYM}_{5}$ & 7.4 & 3.8 & 215 & 14.5 & 132 & 16.2 \\
$\mathrm{~N}_{150} \mathrm{P}_{60} \mathrm{~K}_{90}$ & 7.6 & 0.10 & 200 & 12.2 & 134 & 13.5 \\
$\mathrm{SEm} \mathrm{\#}$ & 0.04 & 0.28 & 1.8 & 0.6 & 0.15 & 0.05 \\
$\mathrm{CD}(\mathrm{P}=0.05)$ & 0.11 & & 5.2 & 1.6 & 4.2 & 1.5 \\
\hline
\end{tabular}

\section{Soil fertility}

$\mathrm{pH}$ of the soil treated without (control) and fertilizer alone remained statistically at par after the crop harvest. The $\mathrm{pH}$ showed decline under treatments receiving FYM. Decrease in $\mathrm{pH}$ may be attributed to organic acids released during decomposition of organic manure. Use of different levels of $\mathrm{K}$ and $\mathrm{FYM}$ caused a marked change in the organic carbon content in postharvest soil. The maximum amount of soil organic carbon $\left(4.5 \mathrm{~g} \mathrm{~kg}^{-1}\right)$ in post-harvest soil was recorded withN $\mathrm{N}_{150} \mathrm{P}_{60} \mathrm{~K}_{60} \mathrm{FYM}_{5}$ treatment. This increase in organic carbon content may be attributed to addition of FYM in soil. There was a decline in nitrogen, phosphorus potassium and sulphur content in control over their initial values. All the treatments applied with FYM showed better status of nutrients in post-harvest soil than the remaining treatments. The highest values of available $\mathrm{N}\left(215 \mathrm{~kg} \mathrm{ha}^{-1}\right)$ and $\mathrm{P}\left(14.5 \mathrm{~kg} \mathrm{ha}^{-1}\right)$ were recorded with $\mathrm{N}_{150} \mathrm{P}_{60} \mathrm{~K}_{60} \mathrm{FYM}_{5}$ treatment. This increase in availability of nutrients with FYM may be owing to the fact that FYM provides a slow release supply of organically bound nutrients such as nitrogen and phosphorus. The FYM accelerates mineral weathering and aids in solubilization of plant nutrient from otherwise insoluble minerals. Application of $\mathrm{N}_{150} \mathrm{P}_{60}$ $\mathrm{K}_{90}$ treatment showed significantly higher amount of available potassium in post-harvest soil. The lowest amount of available $\mathrm{K}\left(96 \mathrm{~kg} \mathrm{ha}^{-1}\right)$ was recorded in control. The higher content of available $\mathrm{K}$ with $90 \mathrm{~kg} \mathrm{~K}_{2} \mathrm{O}$ ha $^{-1}$ may be attributed to increased amount of applied $\mathrm{K}$ in to the soil. Application of $\mathrm{N}_{150} \mathrm{P}_{60} \mathrm{~K}_{60} \mathrm{FYM}_{5}$ increased the amount of available $S$ in post-harvest soil.

It may be concluded from the present study that integrated use of potassium increased the yield and nutrient uptake by wheat. Application of FYM causes better nutrient availability which results better uptake of nutrients from soil. Application of $\mathrm{N}_{150} \mathrm{P}_{60} \mathrm{~K}_{60}$ $\mathrm{FYM}_{5}$ proved beneficial for obtaining the higher production of wheat in alluvial soil of Agra region. 


\section{REFERENCES}

Chesnin, L. and Yien, C.H. (1951)Turbidimetric determination of available sulphate. Soil Science Society of America Proceedings 15: 149-151.

Gomez, K.A.and Gomez, A.A. (1984)Statistical procedures for Agricultural Research. John Willy and Sons, New York.

Jackson, M.L. (1973) Soil Chemical Analysis. Prentice Hall of India Private Limited, New Delhi.

Kumar, Y. Singh, S.P. and Singh, V.P. (2015)Effect of FYM and potassium on yield, nutrient uptake and economics of wheat in alluvial soil. Annals of Plant and Soil Research 17(1): 100-103.

Pandey, M., Singh, S. and Singh, U.N. (2020)Effect of integrated nutrient management on productivity of oat (Avena sativa L.) and soil fertility. Annals of plant and soil Research 20(2): 151155.

Singh, U.N., Singh, R. and Singh, V. (2020) Effect of potassium and sulphur nutrition on yield and uptake of nutrients in Indian mustard (Brassica juncea). Annals of plant and soil Research 20(3): 245-248.

Singh, V. (2020)Effect of integrated nutrient management on yield and uptake of nutrients on pearl millet (Pennisetum glaucum)-mustard (Brassica juncea) crop sequence. Annals of plant and soil Research 22(4): 349-353.

Singh, V. Ali, J., Seema, Kumar, A. and Chauhan, T.M. (2015)Productivity, nutrient uptake and economics of wheat (Triticum aestivum) under potassium and zinc nutrition. Indian Journal of Agronomy 60(3): 426-430.

Singh, V. and Patra, A. (2017)Effect of FYM and Manganese on yield and uptake of nutrients in wheat (Triticum aestivum). Annals of Plant and Soil Research 19(4): 381-384.

Subba Rao, A., Lakaria, B.Land Shirale, A.O. (2017) Integrated potassium management. A/strategy to minimize import dependence. Indian Journal of Fertilizers 13 (4): 114-126. 